\title{
POKORA W WALCE Z PYCHĄ - FUNDAMENTALNY SPÓR MORALNO-DUCHOWY W ROZUMIENIU OJCÓW KAPADOCKICH I JANA CHRYZOSTOMA
}

W rozwoju patrystycznego myślenia o pokorze można dostrzec dwie tendencje, eksponujące wyjątkowe miejsce pokory wśród cnót ${ }^{1}$. Tradycja zapoczątkowana przez Ewagriusza z Pontu ${ }^{2}$ i kontynuowana przez Jana Kasjana $^{3}$ głosiła, że pycha - wada przeciwna pokorze - atakuje człowieka, który jest już zaawansowany na drodze duchowego rozwoju, w związku z czym jej przedstawiciele uważali pokorę za cnotę najdoskonalszą, stanowiącą szczyt i zwieńczenie innych cnót. Natomiast drugie stanowisko, reprezentowane przez Grzegorza Wielkiego ${ }^{4}$ i podjęte przez najnowszy Katechizm Kościoła Katolickiego ${ }^{5}$, uznawało pokorę za cnotę podstawową, która powinna rozpoczynać proces walki duchowej, ponieważ pycha, czyli chęć zajmowania przez człowieka miejsca przeznaczonego Bogu, jest pierwszą i najważniejszą wadą, stanowiącą podstawę każdego grzechu. U niektórych autorów epoki patrystycznej, przykładowo u Ojców Pustyni (np. Doroteusz z Gazy ${ }^{6}$ ), wspomniane hierarchie wad i cnót wzajemnie się przenikały i uzupełniały, a pokora, jako przeciwieństwo głównej wady - pychy, stała się swoistą klamrą z jednej strony zapoczątkowującą, z drugiej - spajającą budowlę cnót chrześcijańskich. Podobne podejście można zauważyć u głównych bohaterów niniejszego artykułu - wybitnych wschodnich Ojców Kościoła IV wieku.

* Ks. prof. dr hab. Mariusz Szram - kierownik Katedry Teologii i Literatury Patrystycznej w Instytucie Historii Kościoła i Patrologii na Wydziale Teologii Katolickiego Uniwersytetu Lubelskiego Jana Pawła II; e-mail: m.szram@wp.pl.

${ }^{1}$ Por. L. Misiarczyk, Osiem logismoi w pismach Ewagriusza z Pontu, Kraków 2007, 17-26.

2 Por. Evagrius Ponticus, Practicus 6, ed. A. Guillaumont - C. Guillaumont, SCh 171, Paris 1971, 506-508.

${ }^{3}$ Por. Joannes Cassianus, De institutis coenobiorum 5, 1, ed. J.C. Guy, SCh 109, Paris 1965 , 190; tenże, Collationes Patrum 5, 2, ed. E. Pichery, SCh 42, Paris 1955, 190.

${ }^{4}$ Por. Gregorius Magnus, Moralia in Iob 31, 87, ed. M. Adriaen - A. de Vogüé, SCh 525, Paris 2009, 338.

${ }^{5}$ Por. KKK 1866.

${ }^{6}$ Por. Dorotheus Gazaenus, Instructiones 14, 151, ed. L. Regnault - J. de Préville, SCh 92, Paris $1963,422-426$. 
Jak wynika z zarysowanego powyżej ogólnego przeglądu stanowisk, pokora $\mathrm{i}$ pycha stanowiły istotną parę wśród walczących między sobą wad i cnót, a wynik tej walki rzutował na kształt życia moralnego i duchowego. Bez zrozumienia roli, jaką przypisywali Ojcowie wadzie pychy, nie jest możliwa właściwa ocena ich nauczania o pokorze. Bardzo często można natrafić w spuściźnie Ojców Kościoła na homilie i traktaty poświęcone wadom, w których znajduje się wręcz „kopalnia” informacji o przeciwstawnych im cnotach $^{7}$. Paradoksalnie, zapewne ze względów pastoralnych, wymuszających najpierw walkę z ludzkimi wadami, wypowiedzi dotyczące pychy pojawiają się częściej niż teksty odnoszące się bezpośrednio do pokory. W moich analizach, zmierzających do ukazania specyfiki fundamentalnej walki toczącej się w duszy i w życiu człowieka między pychą i pokorą, zwrócę więc uwagę na fragmenty dzieł Ojców Kapadockich i Jana Chryzostoma dotyczące zarówno wad i grzechów głównych, jak i najważniejszych cnót.

\section{Według Bazylego Wielkiego - pokora jako najważniejszy środek} zbawczy przeciw pysze. Bazyli Wielki był przekonany, że o upadku pierwszych rodziców zadecydowała pycha, dlatego pokora odgrywa - jego zdaniem - pierwszoplanową rolę w powrocie ludzi do łączności z Bogiem, a jej nabywanie $\mathrm{w}$ procesie doskonalenia jest koniecznością ${ }^{8}$. Do zwrócenia uwagi na pychę jako korzeń ludzkiej grzeszności skłoniły Bazylego nie tylko przesłanki biblijne, ale także sytuacja w Kościele IV wieku, dotkniętym rozbiciem spowodowanym przez herezje, u których podłoża legły - zdaniem Kapadocczyka - zarozumiałość, egoizm i nieposłuszeństwo:

„nigdy nie było takiej jak dzisiaj niezgodności oraz walki między tymi, którzy są w Kościele, wynikającej z odwrócenia się od jednego, wielkiego, prawdziwego Boga i jedynego Króla wszechrzeczy. Każdy odstępuje od nauki Pana naszego Jezusa Chrystusa, broni na własną rękę jakichś myśli i własnych zasad, i woli raczej rządzić stając przeciwko Panu niż być rządzonym przez Pana".

Nieposłuszeństwo wobec Boga jest - według Bazylego - ściśle związane z pychą, stanowi o istocie grzechu, sprzeciwia się woli Jezusa Chrystusa i rozbija jedność Kościoła ${ }^{10}$. Pychę określa Kapadocczyk nawiązując do sformułowań wywodzących się z języka biblijnego: „wyniosłość (

\footnotetext{
${ }^{7}$ Przykładem mogą być współczesne Kapadocczykom pisma Ewagriusza z Pontu, a zwłaszcza dwa traktaty: Practicus (ed. A. Guillaumont - C. Guillaumont, SCh 170-171, Paris 1971) i De octo spiritibus malitiae (PG 79, 1145A-1164D).

${ }^{8}$ Problemowi pychy poświęcił Bazyli w całości jedną ze swoich homilii, która zachowała się jedynie w przekładzie arabskim. Por. Basilius Caesariensis, Homilia de superbia, ed. J. Muyser, Homilie des hl. Basilius über den Hochmut der Jugend und die Demut des Alters (arabice), Kairo 1954.

${ }^{9}$ Tenże, De iudicio Dei 2, PG 31, 655A-B, thum. J. Naumowicz: Św. Bazyli Wielki, O sądzie Bożym, w: Św. Bazyli Wielki, Pisma ascetyczne, I, ŹM 5, Tyniec - Kraków 1994, 63-64.

${ }^{10}$ Por. tamże 4, PG 31, 661A-B.
} 
przeciwna poznaniu Boga” (por. 2Kor 10, 4-6), „,wzgardzenie słowem Pana i złamanie Jego przykazań” (por. Lb 15, 30-31) ${ }^{11}$, ,pielęgnowanie myśli, któ-

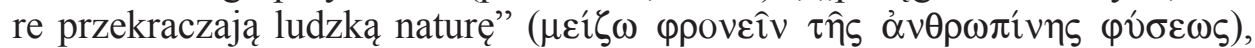

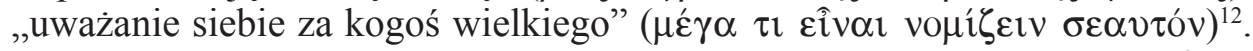

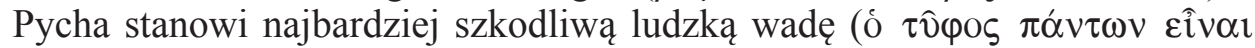

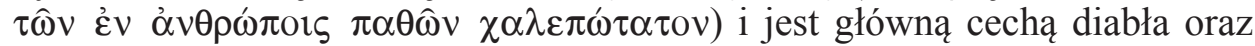
tych, którzy mu służą ${ }^{13}$. Szczególne miejsce wśród takich osób zajmują heretycy, przykładowo Eunomiusz, przeciw któremu Bazyli napisał traktat silnie zabarwiony inwektywą. Pychę arian, których przedstawicielem jest wspomniany Eunomiusz, określił w tym dziele jako nieodpartą chęć przeniknięcia umysłem ludzkim substancji samego Boga, podczas gdy jest ona niedostępna, a ludzie nie potrafią zgłębić do końca nawet natury otaczającego ich świata ${ }^{14}$.

Bazyli mocno akcentował fakt, że pycha jest skrajnym przeciwieństwem pokory. Obu postaw nie da się w żaden sposób połączyć, podlegają one całkowicie odmiennej ocenie moralnej. Pycha niszczy wszelkie dobre owoce w procesie doskonalenia chrześcijanina. Pokora natomiast umożliwia duchowy wzrost i skutecznie go zabezpiecza ${ }^{15}$. W dziele De origine hominis Kapadocczyk skontrastował z prawdą o człowieku stworzonym z prochu ziemi zretoryzowane przedstawienie człowieka pysznego odzianego w bogate szaty, otoczonego tłumem podwładnych oddających mu cześćc ${ }^{6}$. Podstawowe odmiany pychy wyszczególnione przez Bazylego to: wywyższanie się

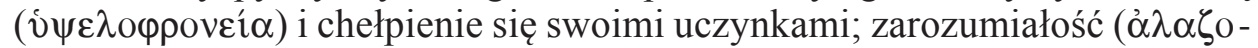
veí $\alpha$ ) polegająca na łamaniu ustanowionych praw i poszukiwaniu własnych zasad życia; duma (i $\pi \varepsilon \rho \eta \varphi \alpha v \varepsilon i ́ \alpha$ ) usiłująca pokazać się większym niż się jest $\mathrm{w}$ istocie ${ }^{17}$.

Bazyli, uprzedzając Augustyna, uznał, że brak wyniosłości (ỏ charakteryzujący pokorę, jest największym środkiem zbawczym ( $\mu \varepsilon \gamma i \sigma \tau \eta$ $\sigma \omega \tau \eta \rho i ́ \alpha)$ dla człowieka, lekiem na chorobę grzechu, umożliwiającym powrót do stanu pierwotnego ${ }^{18}$. Mówił o tym używając terminów Pawłowych. Ostrzegał przed przywłaszczaniem sobie otrzymanych darów:

\footnotetext{
${ }^{11}$ Por. tamże 6, PG 31, 665B-667C.

${ }^{12}$ Por. tenże, De origine hominis 1, 19, ed. A.Smets - M. van Esbroeck, SCh 160, Paris1970, 218.

${ }^{13}$ Por. tenże, Adversus Eunomium 1, 13, ed. B. Sesboüé - G.M. de Durand - L. Doutreleau, I, SCh 299, Paris 1982, 218; tamże 1, 3, SCh 299, 160.

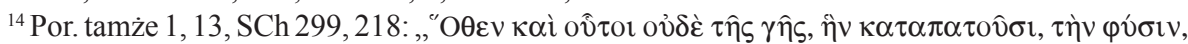

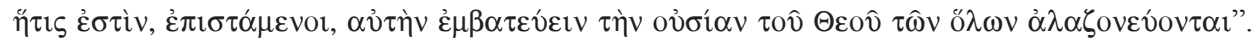

${ }_{15}$ Por. tenże, Asceticon magnum sive Quaestiones (Regulae fusius tractatae) 29, PG 31, 989D-991A.

${ }^{16}$ Por. tenże, De origine hominis 2, 13, SCh 160, 264-266.

${ }^{17}$ Por. tenże, Asceticon magnum sive Quaestiones (Regulae brevius tractatae) 56, PG 31, 1119C-1121A.

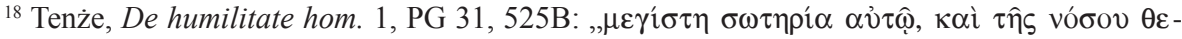

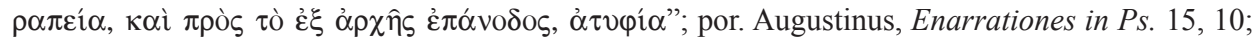
tenże, De fide et symbolo 4, 5.
} 
„To nie ty poznałeś Boga przez twoją własną sprawiedliwość, ale to Bóg poznał ciebie przez swoją dobroć. [...] To nie ty zdobyłeś Chrystusa przez cnotę, ale to Chrystus zbawił cię przez swoje przybycie"19.

W świetle powyższych stwierdzeń pokora staje się nie mniej konieczna dla sprawiedliwego niż dla grzesznika. Wszyscy ludzie zostali dotknięci grzechem pychy, który uniemożliwia zbawienie. Jedynym lekarstwem jest przyjęcie z pokorą daru usprawiedliwiającej łaski przyniesionego przez Chrystusa.

2. Według Grzegorza z Nazjanzu - pokora w poznaniu Boga zabezpieczeniem przed pychą heretyków i płytkich teologów. „Pychę poskramiał,

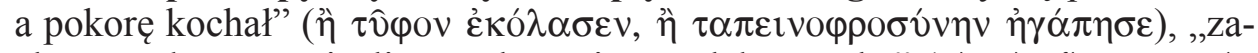
chowywał wstrzemięźliwość, lecz nie wpadał w pychę" ( $\tau$ ò $\mu \dot{\varepsilon} v$ ív $\alpha \kappa \alpha \theta \alpha i$ $\rho \eta \tau \alpha$, ív $\alpha \mu \grave{\eta}$ i $\pi \varepsilon \rho \alpha i \rho \eta \tau \alpha \imath)$, ,prowadząc wzniosłe życie nie utracił pokory

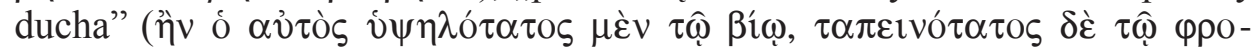
$v \eta \dot{\mu} \mu \tau \imath)^{20}-$ za pomocą powyższych antytetycznie sformułowanych pochwał pod adresem własnego ojca, będących równocześnie swoistymi ekshortacjami moralnymi, Grzegorz z Nazjanzu ukazywał przepaść dzielącą postawy pokory i pychy. Pokora jako cnota szczególnie pożądana została w powyższych zestawieniach konsekwentnie przeciwstawiona pysze jako postawie, której trzeba zdecydowanie unikać.

Polemizując z heretykami swojego czasu, głównie arianami, Grzegorz zwrócił uwagę na szczególny przejaw pychy, na który powinien być wrażliwy duchowny i teolog, mianowicie nieumiarkowanie w mówieniu o Bogu i pozbawione poszanowania tajemnicy zagłębianie się w Jego naturę. „Pseudoteologów" roszczących sobie prawo do rozważania Bożych prawd oskarżył o „ga-

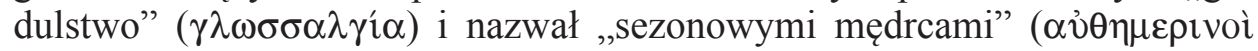

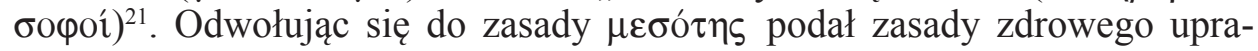
wiania teologii, któremu musi towarzyszyć umiar i skromność, czyli postawy związane z pokorą:

„Nie każdy, moi drodzy, może o Bogu rozprawiać, nie każdy! Nie tak to prosta sprawa i nie dla ludzi, którzy po ziemi chodzą! A dodam i to, że nie byle kiedy, i nie wobec wszystkich, i nie o wszystkim, ale czynić to trzeba na cza-

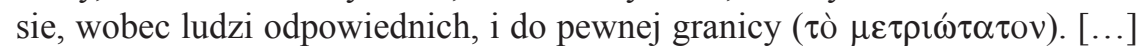
O czym więc rozprawiać i w jakim zakresie? O tym, co sami pojąc możemy i do jakiej granicy dochodzi pojętność słuchającego i wytrzymałość, by prze-

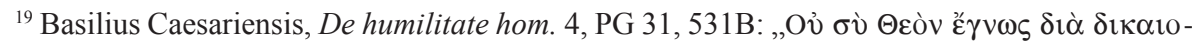

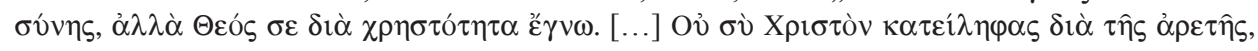

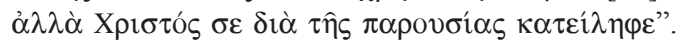

${ }^{20}$ Por. Gregorius Nazianzenus, Orationes 18, 23, PG 35, 1011B-1013A, thum. J.M. Szymusiak, w: Grzegorz Teolog. U źródet chrześcijańskiej myśli IV wieku, Poznań 1965, 333.

${ }^{21}$ Por. tamże 20, 1, PG 35, 1065A, thum. zbiorowe, w: Św. Grzegorz z Nazjanzu, Mowy wybrane, red. S. Kazikowski, Warszawa 1967, 218. 
sada w słowach nie zaszkodziła słuchaniu, tak jak przesada w pożywieniu szkodzi ciału"22.

„Skromnym w mych oczach jest [...] ten, kto z umiarkowaniem o Bogu mówi

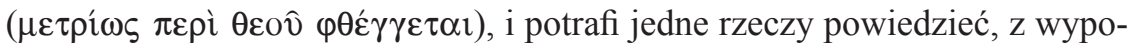
wiedzeniem innych się wstrzymać, a w jeszcze innych otwarcie wyznać swą niewiedzę. Taki ustępuje z mową temu, komu powierzono nauczanie, i spokojnie przyjmuje fakt, że ktoś został obdarzony większą łaską Ducha i w roz-

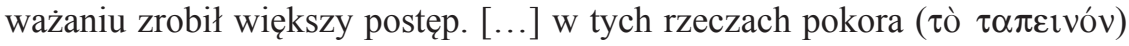
oprócz chwały zapewnia i wolność od trosk i poczucie bezpieczeństwa"23.

Szczególną krytykę kierował Grzegorz pod adresem duchownych, którzy zamiast z pokorą zdobywać wiedzę teologiczną pysznili się z posiadania zaledwie nikłych jej podstaw:

„wszyscy jesteśmy w tym punkcie tak źle przygotowani, że większość spośród nas - by nie powiedzieć wszyscy - zanim dochodzimy do pierwszych postrzyżyn zaprzestajemy po dziecinnemu wyrażać się, zanim zaczynamy uczęszczać do kościoła, zanim poznajemy choćby tytuł świętych ksiąg, zanim nauczymy się rozróżniać Nowy Testament od Starego oraz poznawać ich autorów - nie powiedziałbym, zanim chrzest oczyszcza nas z grzechu [pierworodnego] i dusze obmywa ze śladów zostawionych przez własne grzechy - wyuczamy się zaledwie dwóch czy trzech zdań o religii, i to ze słyszenia, nie z czytania, albo lekko zapoznajemy się z [psalmami] Dawida, i już ubieramy się w płaszcz studencki, albo dopasowujemy sobie szatę ascety [,filozofa”], nadając sobie samym znamiona i wygląd religijności. Takie to - o dziwo! - nasze prawo do pierwszeństwa, taka nasza zarozumiałość! Każdy Samuel jest święty od kołyski! Od razu stajemy się mędrcami i nauczycielami! Od razu jesteśmy biegłymi w sprawach Bożych i zajmujemy pierwsze miejsce wśród uczonych i biegłych w Piśmie, sami wyświęcamy się na duchownych i ubiegamy u ludzi o tytuł Rabbiego. Gardzimy literą, wyrokując, że wszystko należy pojmować duchowo. Wszelkie nasze wymysły stają się jedną wielką bzdurą, unosimy się, jeśli nas nie wychwalają. Taka jest postawa najlepszych i najskromniejszych wśród nas. A jaka dopiero tych bardziej uduchowionych i szlachetnych!"24.

W świetle powyższej diagnozy kondycji pysznych duchownych najlepszym lekarstwem - zdaniem Grzegorza - jest porzucenie nadętych myśli o własnym znaczeniu, walka z próżnością, która jest wielką przeszkodą na drodze do cno-

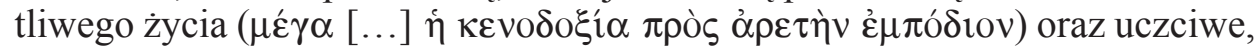
cierpliwe i długotrwałe zdobywanie mądrości, czyli wiedzy z zakresu zagadnień boskich i ludzkich ${ }^{25}$.

${ }^{22}$ Tamże 27, 3, ed. P. Gallay, SCh 250, Paris 1978, 76-78, Mowy wybrane, 276.

${ }^{23}$ Tamże 32, 19, ed. P. Gallay - C. Moreschini, SCh 318, Paris 1985, 124-126, Mowy wybrane, 375.

${ }^{24}$ Tamże 2, 49, ed. J. Bernardi, SCh 247, Paris 1978, 154-156, thum. Szymusiak, 272.

${ }^{25}$ Por. tamże 2, 50-51, SCh 247, 156-158, thum. Szymusiak, 272-273. 
3. Według Grzegorza z Nyssy - pycha poniża, pokora wywyższa. Grzegorz z Nyssy jeszcze bardziej dobitnie i wyraźnie niż pozostali Ojcowie Kapadoccy wypowiadał się na temat pychy jako przyczyny i początku wszelkiego zła i grzechu:

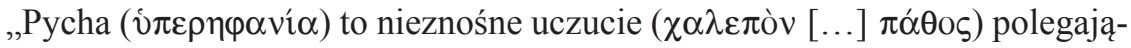
ce na chęci przewyższenia innych, które można bez niebezpieczeństwa odejścia od prawdy nazwać nasieniem $(\sigma \pi \varepsilon ́ \rho \mu \alpha)$ lub korzeniem ( $\rho i ́ \zeta \alpha)$ wszelkiego grzechu"26;

„,̇adne inne zło, [którego dopuszcza się] ludzka natura nie jest gorsze od choroby pychy (i $\left.\pi \varepsilon \rho \eta \varphi \alpha v^{\prime} \alpha\right)^{\prime 27}$.

Podczas toczącej się w człowieku walki duchowej między wadami i cnotami zarozumiała wyniosłość i znające miarę uniżenie występują przeciw sobie w jednej z najważniejszych par:

„nieprzyjaciółmi, którzy walczą jak Egipcjanin z Hebrajczykiem, są bałwochwalstwo i prawdziwa pobożność, rozwiązłość i wstrzemięźliwość,

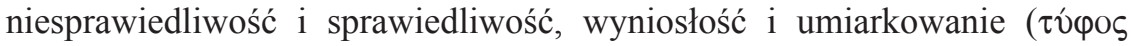

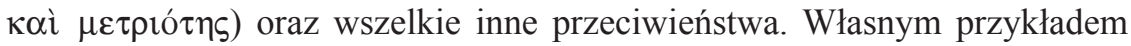
Mojżesz uczy nas, byśmy stanęli po stronie cnoty, jak przy rodaku, i zabili wroga, który napada na cnotę. Istotnie bowiem zwycięstwo prawdziwej pobożności oznacza śmierć i zagładę bałwochwalstwa. Tak samo sprawiedliwość niszczy niesprawiedliwość, a umiarkowanie niweczy wyniosłość ( $\tau \hat{n}$

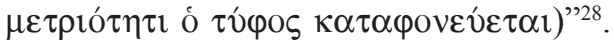

W przytoczonym tekście Grzegorz wprawdzie nie wyeksponował pychy i pokory w pierwszej parze, niemniej należy pamiętać, że zaproponowane przez niego wyliczenie zwalczających się wzajemnie cnót i wad było związane z egzegezą, a nie z filozoficzno-teologiczną systematyzacją. Wymienienie

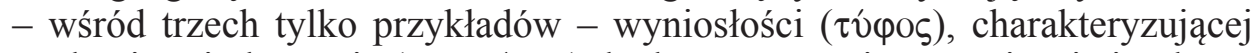
pychę, i umiarkowania ( $\mu \varepsilon \tau \rho ı$ ó $\eta \varsigma)$, będącego synonimem uniżenia i pokory, dowodzi jednak, że mamy do czynienia z niezwykle ważną, wręcz kluczową parą, od której zależy bardzo wiele w życiu duchowym.

W swoim katalogu wad, nawiązującym do św. Pawła (por. Rz 1, 28-32), Grzegorz z Nyssy postawił pychę na równi z zabójstwem ( óvos) oraz wezwał do unikania wszelkiej czci ludzkiej i pochwał pochodzących z ust człowie-

${ }^{26}$ Gregorius Nyssenus, De virginitate IV 2, 11-15, ed. M. Aubineau, SCh 119, Paris 1966, 306-

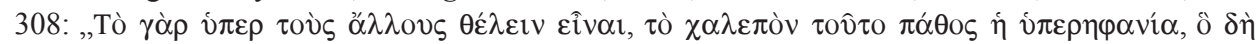

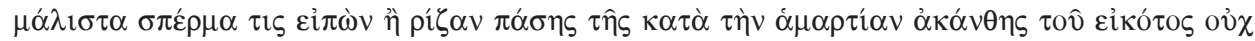
$\dot{\alpha} \mu \alpha \rho \tau \eta \dot{\sigma \varepsilon \tau} \alpha \imath[\ldots] "$.

${ }^{27}$ Tenże, De beatitudinibus orationes 1, ed. J.F. Callahan, GNO 7/2, Leiden 1992, 83, thum. M. Przyszychowska: Grzegorz z Nyssy, Homilie do błogosławieństw, ŹMT 34, Kraków 2005, 36.

${ }^{28}$ Tenże, De vita Moysis 2, 14, ed. J. Daniélou, SCh 1bis, Paris 1968, 114, thum. S. Kalinkowski: Grzegorz z Nyssy, Życie Mojżesza, ŹMT 50, Kraków 2009, 45 (thum. poprawione). 
ka, zachęcił natomiast do zabiegania o podobanie się tylko Bogu przez życie zgodne z Jego przykazaniami i pragnienie wiecznej chwały ${ }^{29}$. Oddalenie od siebie pychy przez wzgląd na bojaźn wobec Boga i zachowanie pokory uważał

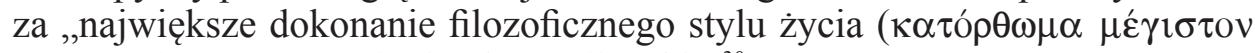

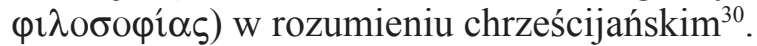

Pycha jest - w przekonaniu Nysseńczyka - wadą o niezwykle przewrotnej naturze. W De vita Moysis podał on dwie jej definicje, które zdają się sobie przeczyć. Jedna wiąże się z powszechnym rozumieniem pychy:

„Większość [...] uważa, iż «pycha» oznacza, że ktoś stoi wyżej od innych (

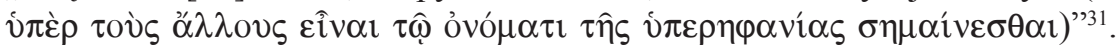

Grzegorz nie zgadzał się jednak z tym obiegowym przekonaniem. Odwołując się do alegorycznej interpretacji sytuacji, jaka nastąpiła wśród Izraelitów po inwazji jadowitych węży i ratunku przyniesionym przez węża wywyższonego przez Mojżesza na drzewie, sformułował swoją własną definicję pychy, skupiającą się na skutkach, do jakich ta postawa prowadzi:

„Skoro [...] ziemia przestała rodzić węże atakujące ludzi ogarniętych pożądliwością, ponieważ uwierzyli w Tego, który został wywyższony na drzewie, i przekonali się, że są silniejsi od jadowitych ukąszeń, wówczas, gdy już została pokonana pożądliwość, pojawia się pycha. Uznając, że upokarzające jest zadowalanie się wyznaczonym im miejscem, zaczęli domagać się dla siebie godności kapłańskiej, chcąc pozbawić jej tych, którzy ją otrzymali od Boga. Uzurpatorzy zginęli pochłonięci przez ziemię, a to, co z nich pozostało na ziemi, zniszczył piorun. Wydaje mi się, że w tym opowiadaniu Pismo poucza nas, iż rozrost pychy kończy się upadkiem pod ziemię. Być może na tej podstawie można nie bez racji zdefiniować pychę jako «wspinanie się w dół»

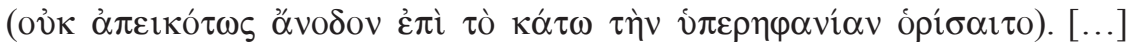
Jeśli bowiem ci, którzy sami wywyższyli się ponad innych, zostali strąceni w dół i pochłonięci przez ziemię, to nie można odrzucić naszego określe-

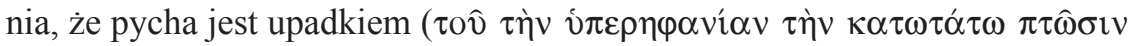

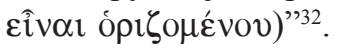

Pycha jest więc - według Grzegorza z Nyssy - swoistą karykaturą pokory. $\mathrm{O}$ ile pokora jest dobrowolnym zachowaniem umiaru oraz uniżeniem się przed Bogiem i ludźmi, o tyle pycha prowadzi przez samowolne wywyższenie do jeszcze większego i niechcianego uniżenia, wręcz upadku w grzech. Można streścić myśl Nysseńczyka następująco: kto nie chce sam się uniżyć, zgodnie

${ }^{29}$ Por. tenże, De instituto christiano 25-26. 30, ed. W. Jaeger, GNO 8/1, Leiden 1963, 52 i 54, tłum. J. Naumowicz: Św. Grzegorz z Nyssy, O celu życia i prawdziwej ascezie, w: Św. Grzegorz z Nyssy, O naśladowaniu Boga. Pisma ascetyczne, BOK 15, Kraków 2001, 107-109.

${ }^{30}$ Tamże 56, GNO 8/1, 66, BOK 15, 117.

${ }^{31}$ Tenże, De vita Moysis 2, 281, SCh 1bis, 296, ŹMT 50, 90.

${ }^{32}$ Tamże 2, 280-281, SCh 1bis, 294-296, ŹMT 50, 90. 
ze swoją naturą bytu stworzonego skłonnego do grzechu, ten zostanie poniżony przez własną pychę. Kto natomiast pokornie się uniży, zostanie wywyższony przez swoją pokorę ${ }^{33}$.

4. Według Jana Chryzostoma - pokora w walce z pychą na wszystkich etapach życia duchowego. Wyjątkowe miejsce pokory wśród innych cnót jest - w opinii Jana Chryzostoma wyrażonej jeszcze jaśniej i dosadniej niż u Kapadocczyków - ściśle uwarunkowane naczelną pozycją, jaką wśród grzechów

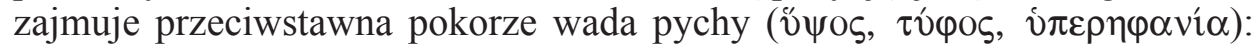
„Nic nie jest wznioślejsze od pokory, nic bardziej od pychy godne pogardy”34.

Pycha łączy się z próżną chwałą ( $\kappa \varepsilon v o \delta o \xi i ́ \alpha)$, zazdrością ( $\beta \alpha \sigma \kappa \alpha v i ́ \alpha)$, za-

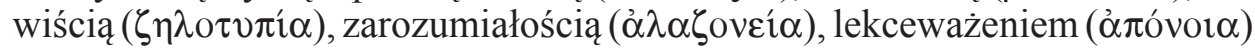
i gniewem $(\theta v \mu o ́ \varsigma)$, pierwszymi wadami, które wdzierają się do duszy ludzkiej, poprzedzając nieczystość i skąpstwo ${ }^{35}$. To pycha ( $\left.\tilde{\pi} \varepsilon \rho \eta \varphi \alpha v i \alpha\right)$ stała się przyczyną upadku szatana i pierwszych rodziców ${ }^{36}$. Nie ma wady bardziej obcej chrześcijańskiej duszy. Jest ona skutkiem infantylizmu i niedojrzałości ${ }^{37}$. Polega na nierozpoznaniu Boga lub na buntowaniu się przeciw Niemu. Jest

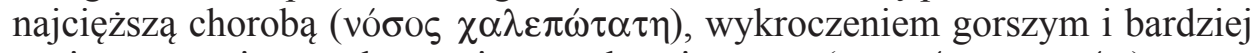

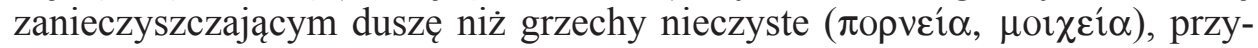
czyną ( $\dot{\imath} \zeta \zeta$ ) wszystkich innych złych czynów ${ }^{38}$.

Według Chryzostoma pycha jest wadą antyludzką i antyspołeczną, ponieważ jej istotę stanowi zamykanie się w samowystarczalności i samouwielbieniu oraz niedostrzeganie wokół siebie ani ludzi oczekujących pomocy, ani takich, którzy mogliby w czymkolwiek pomóc ${ }^{39}$. Wobec szczególnej szkodliwości pychy pokora staje się cnotą wielce pożądaną. Jej oddziaływanie złotousty kaznodzieja charakteryzował za pomocą obrazowych porównań. Podobnie jak pycha (ảróvoı $\alpha$ ) z powodu wielkiego ciężaru swojej masy przeważa

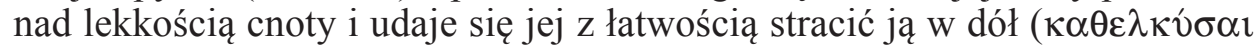

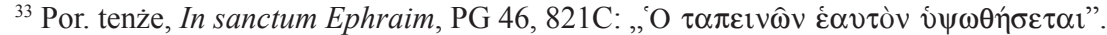

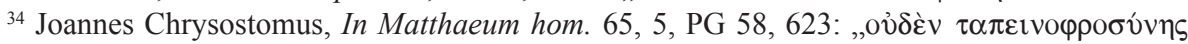

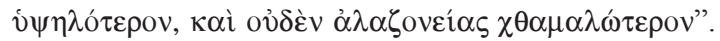

${ }^{35}$ Por. tenże, Ad Theodorum lapsum epistula 1, 1, ed. J. Dumortier, SCh 117, Paris 1966, 50; tenże, In Epistulam II ad Corinthios hom. 28, 2, PG 61, 591-592; tenże, In Matthaeum hom. 65, 5, PG 58, 623-624. Pysze i dążeniu do próżnej chwały poświęcił Chryzostom oddzielną homilię, z której zachowały się tylko fragmenty. Por. tenże, Ecloga 16. De superbia et inani gloria, PG 63, 671-678.

${ }^{36}$ Por. tenże, In illud: Vidi Dominum, hom. (In Osiam hom.) 3, 4, ed. J. Dumortier, SCh 277 , Paris 1981, 124.

${ }^{37}$ Por. tenże, In Epistulam ad Philippenses hom. 5, 2-3, PG 62, 215-216.

${ }^{38}$ Por. tenże, In Joannem hom. 16, 4, PG 59, 106.

${ }^{39}$ Por. tenże, In Epistulam II ad Corinthios hom. 17, 2, PG 61, 520-521; tenże, In Epistulam ad Philippenses hom. 5, 3, PG 62, 216-217. Według Jana Chryzostoma człowiek pyszny boi się jakiegokolwiek niedostatku, ponieważ będzie musiał skorzystać z pomocy innych, a to poniżałoby jego wyniosłą godność.
} 


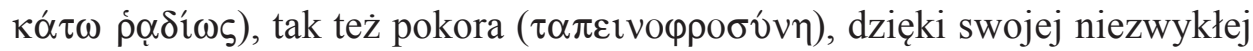

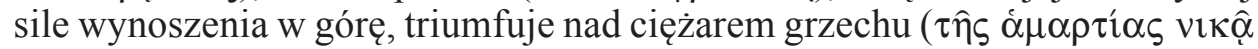

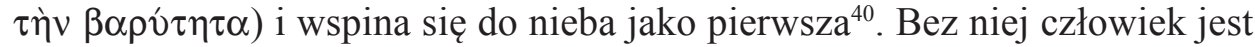
nieczysty (’̊Kó $\theta \alpha \rho \tau o \varsigma)$, staje się godny przekleństwa i pogardy, nie może osiągnąć zbawienia; z nią natomiast odzyskuje szczęście ( $\mu \alpha \kappa \alpha \rho \iota \omega ́ \tau \varepsilon \rho \circ \varsigma)$, wart jest podziwu, staje się umiłowany przez Boga i szanowany przez ludzi ${ }^{41}$. Dzięki pokorze rodzą się w człowieku takie dobra ( $\left.\alpha \gamma \alpha \theta \alpha ́\right)$, jak: wy-

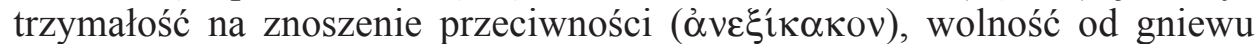

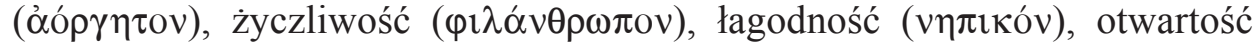
na cudze potrzeby $(\pi \rho \circ \sigma \varepsilon \kappa \tau \iota \kappa o ́ v)^{42}$. Obszerne porównanie pychy i pokory umieszcza Chryzostom w jednej z homilii o Ewangelii św. Mateusza, odwołując się zarówno do retorycznego paradoksu, jak i do nauki Chrystusa:

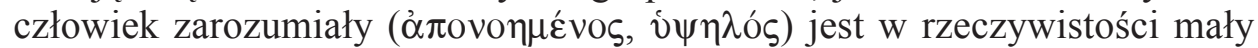

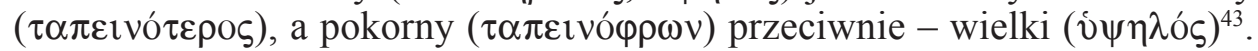
Pyszny znajduje się pod wpływem diabła, pokorny zrównuje się z aniołami ${ }^{44}$. Pycha stanowi przedmiot największego Boskiego obrzydzenia i jest szczytem zła, podczas gdy pokora jest szczególnie miła Bogu ${ }^{45}$. Kontrast między obiema postawami wyraził Chryzostom za pomocą paradoksu nawiązującego do słów ewangelicznych:

„Zarozumiałość (ỏđóvoı $\alpha$ ) nie tylko nie daje nam w życiu nic dobrego, lecz nawet zabiera nam to, co mamy. Przeciwnie zaś pokora ( $\tau \alpha \pi \varepsilon ı v o-$

${ }^{40}$ Por. tenże, De incomprehensibili Dei natura (Contra Anomoeos hom.) V 517-522, ed. A.M.

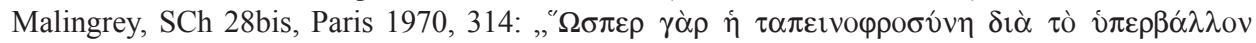

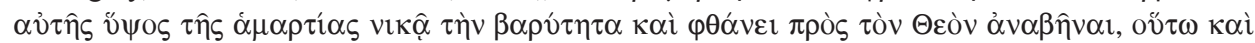

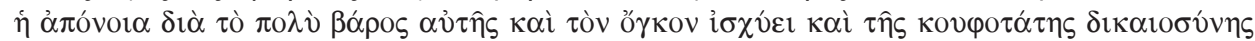

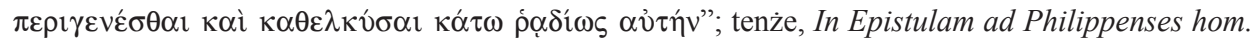
7, 5-6, PG 62, 236.

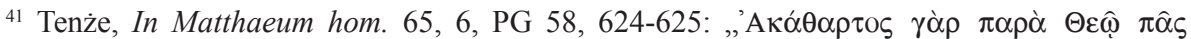

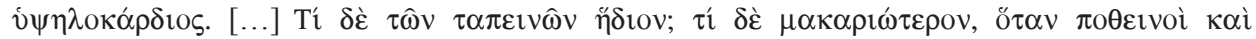

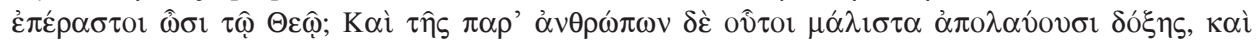

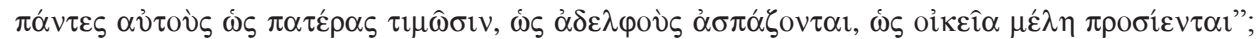
por. tamże 47, 3, PG 58, 484-485; 64, 4, PG 58, 615; tenże, In Acta Apostolorum hom. 30, 3, PG 60, 225; tenże, In Epistulam ad Romanos hom. 1, 3, PG 60, 399; 20, 3, PG 60, 599; tenże, In epistulam I ad Corinthios hom. 1, 2, PG 61, 15.

${ }^{42}$ Por. tenże, In epistulam ad Philippenses hom. 7, 5, PG 62, 236.

${ }^{43}$ Por. tenże, In Matthaeum hom. 65, 5, PG 58, 623.

${ }^{44}$ Por. tenże: In illud: Vidi Dominum, hom. (In Osiam hom.) 3, 3, SCh 277, 122.

${ }^{45}$ Por. tenże, In Matthaeum hom. 65, 6, PG 58, 623-625, thum. A. Baron - J. Krystyniacki: Św. Jan Chryzostom, Homilie na Ewangelię wedtug św. Mateusza. Część druga: homilie 41-90, ŹMT 23, Kraków 2001, 286-289; tenże, In Epistulam ad Philippenses hom. 7, 6, PG 62, 238. Oparte na obserwacjach psychologicznych porównania ludzi cnotliwych i grzeszników są specjalnością Chryzostoma. W innej homilii przedstawia z jednej strony opłakany stan pyszałka, który żąda pochwał i cierpi, bo ich nie otrzymuje; z drugiej - „stoicki” spokój człowieka pokornego, który nie szuka poklasku, cieszy się, gdy je usłyszy, ale nie martwi się, gdy ich nie doznaje, por. tenże, In Acta Apostolorum hom. 16, 4, PG 60, 132; tenże, In Epistulam I ad Corinthios hom. 1, 3, PG 61, 15-16. 


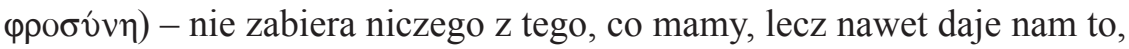
czego nie mamy"46.

Pokora jako wolność od pychy staje się - w przekonaniu Jana - podstawą cnoty i zasługuje na wieczną nagrodę:

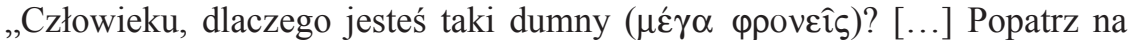
tego, który ubrany jest nie w szaty, lecz w cnotę, a zobaczysz, że jesteś podobny do gnijącej trawy, a on do drzewa, które wydaje cudowne owoce i które sprawia wielką radość patrzącym na nie. [...] Człowiek przyodziany w cnotę posiada szatę, której nie potrafi zniszczyć nie tylko mól, ale nawet sama śmierć" ${ }^{47}$.

Wprawdzie w powyższym tekście jest mowa o cnocie w ogólności, ale wcześniej Złotousty wyraźnie mówił, że chodzi mu o człowieka cierpliwe-

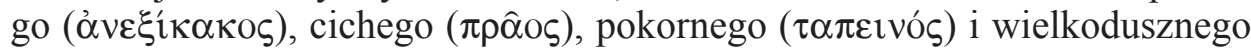
$(\mu \alpha \kappa \rho o ́ \theta v \mu о \varsigma)^{48}$. Ona jest dla niego synonimem i zasadą cnoty w ogóle, ponieważ niszczy postawę najbardziej szkodliwą dla życia duchowego.

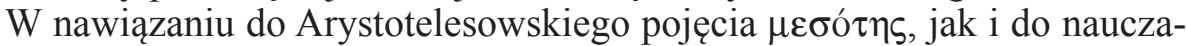
nia św. Pawła, Jan Chryzostom porównywał pychę do wrzodu, który puchnie

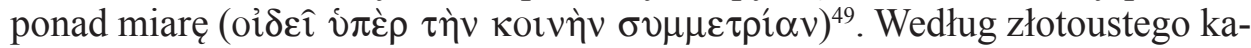
znodziei, mówiącego z retoryczną emfazą i używającego przesadnych porównań mających odstraszyć słuchaczy od ulegania pokusie pychy, jest ona przede wszystkim wadą umysłu, który nie słucha Boga, przekracza miarę i grzeszy zarozumiałością, wreszcie popada w stan najwyższej głupoty i obłąkania:

„ci, którzy puszą się ze swej mądrości, [...] popadają w najwyższe szaleństwo ( $\alpha$ đóvoı $\alpha$ ), gdyż nic tak nie ogłupia, jak szaleństwo. [...] Szaleństwo bowiem, odstępując od umiarkowania i od rozumu (dlatego też nazywa się [dosłownie] nierozumnością), czyni ludzi głupimi i próżnymi. Jeżeli początkiem mądrości jest bojaźń Pana (por. Prz 9, 10), to początkiem głupoty - Jego nieznajomość. Jeżeli więc znajomość Jego jest mądrością i nieznajomość głupotą, a niewiedza ta powstaje z pychy (gdyż początkiem pychy jest nieznajomość Pana), to

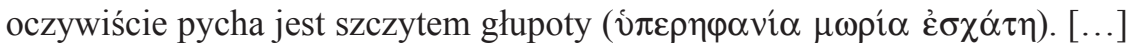
Jak ciało, gdy utraci właściwy dla niego skład soków, i nasiąka zgubną ich mieszaniną, staje się podatne na wszelkie choroby, tak i dusza, kiedy pozbawiona zostanie szlachetnej natury i pokory, znalazłszy się w stanie osłabienia,

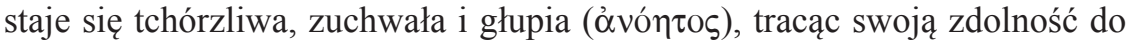
samo-poznania" 50 ;

${ }^{46}$ Tenże, In Matthaeum hom. 65, 6, PG 58, 626, ŹMT 23, 288-289.

${ }^{47}$ Tamże 23, 10, PG 57, 320, thum. J. Krystyniacki: Św. Jan Chryzostom, Homilie na Ewangelię wedlug św. Mateusza. Część pierwsza: homilie 1-40, ŹMT 18, Kraków 2000, 298.

${ }^{48}$ Por. tamże.

${ }^{49}$ Por. tenże, In Epistulam I ad Corinthios hom. 12, 1, PG 61, 97.

${ }^{50}$ Tenże, In Epitulam ad Romanos hom. 20, 4, PG 60, 600, tłum. T. Sinko: Św. Jan Chryzostom, Homilie na list św. Pawła do Rzymian, I/1, Kraków 1995, 335-336. Por. tenże, In Epistulam I ad 


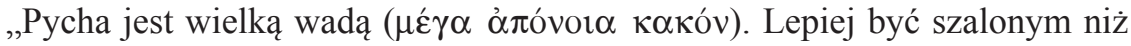
pysznym. Choroba psychiczna jest słabością pochodzącą z natury, pycha jest gorszym obłędem: to często szał połączony z furią ( $\left.\mu \omega \operatorname{pí}^{\alpha}[\ldots] \mu \varepsilon \tau \dot{\alpha} \mu \alpha v^{\prime} \alpha \varsigma\right)$. Biedny szaleniec szkodzi tylko sobie, pyszałek jest plagą dla swoich braci"s1.

W przesiąkniętym retoryką opisie pychy Jan Chryzostom nawiązał do staro-

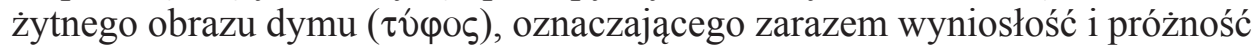
człowieka pysznego, jak i ulotność jego mniemań:

„czy [...] nie zrobiłeś z siebie cudaka, gdy będąc człowiekiem próbujesz latać? A może raczej masz skrzydła w głowie i nadymasz się na wszystkie strony? Czym mam cię nazwać, by pozbawić cię zarozumiałości ( $\alpha$ đóvor $\alpha)$ ? Czyż mam cię nazwać popiołem, prochem, dymem, kurzem? Określiłem twoją bezwartościowość, ale jeszcze nie uchwyciłem dokładnie obrazu, jaki chciałem przywołać. Zamierzam przecież przedstawić całą nadętość i pustkę. [...] Odnoszę wrażenie, że [tacy osobnicy] podobni są do zapalonych pakuł, bo i pakuły po podpaleniu zdają się nadymać i wznosić do góry, a pod lekkim dotknięciem ręką wszystko opada i okazuje się lichszym od jakiegokolwiek popiołu. [...] Zarozumiałość czyni nas łatwymi do pojmania przez kogokolwiek, gdyż [...] łatwiej pryska niż bańka na wodzie, prędzej się rozrywa niż

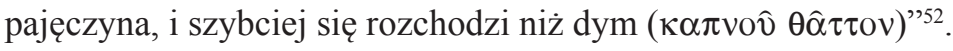

Tak rozumianej niszczącej sile pychy przeciwstawił Jan Chryzostom moc pokory, która pokonuje skutecznie pokusy szatana:

„Aby [...] kroczyć po twardej skale, porzućmy [zarozumiałość], a wybierzmy pokorę. [...] Jest ona mocniejsza od skały i twardsza od żelaza, daje nam większe bezpieczeństwo niż wieże, miasta i mury, gdyż góruje nad wszel-

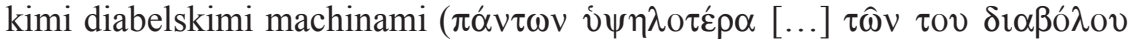
$\mu \eta \chi \alpha \nu \eta \mu \alpha ́ \alpha \omega \nu)^{\prime \prime 53}$.

W tej antydemonicznej potędze pokory pobrzmiewa wyraźnie duch apoftegmatów Ojców Pustyni ${ }^{54}$.

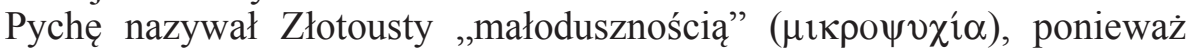
uważa ona za wielkie i godne pochwały to, co czysto ludzkie. Pokora natomiast jest ,wielkodusznością" ( $\mu \varepsilon \gamma \alpha \lambda o \psi v \chi i \alpha)$, gdyż charakteryzuje ona człowieka, który rozpoznaje i uznaje swoją kondycję bytu stworzonego, gardzi

Corinthios hom. 1, 3, PG 61, 15-16; tenże, In Epistulam II ad Thessallonicenses hom. 1, 2, PG 62, 470-471; tenże, In Epistulam I ad Timotheum hom. 17, 1, PG 62, 591-592.

${ }^{51}$ Tenże, In Epistulam ad Philippenses hom. 7, 5, PG 62, 235-236, tłum. własne.

${ }^{52}$ Tenże, In Epitulam ad Romanos hom. 20, 4, PG 60, 601-602, thum. Sinko, I/1, 337. Por. tenże, In Epistulam I ad Corinthios hom. 12, 1, PG 61, 97.

${ }^{53}$ Tenże, In Epistulam ad Romanos hom. 20, 4, PG 60, 602, tłum. Sinko, I/1, 337-338.

${ }^{54}$ Por. Apophtegmata Patrum. Collectio systematica XV 40, ed. J.C. Guy, SCh 474, Paris 2003 , 314; tamże, XV 84, SCh 474, 338-340. 
sobą w obliczu Boga, a za wielkie uznaje tylko to, co Boskie ${ }^{55}$. W sposób paradoksalny następuje $\mathrm{w}$ tych stwierdzeniach Jana zamiana znaczeń terminów antycznych. To, co nazwał on małodusznością pokrywa się w dużym stopniu z tym, co Arystoteles rozumiał przez wielkoduszność. Natomiast to, co Jan określił tym ostatnim terminem, ma charakter typowo chrześcijański, ewangeliczny, nieznany w starożytności.

W dziełku $O$ wychowaniu dzieci autor poświęcił wiele miejsca ściśle związanej z pychą wadzie dążenia do próżnej chwały i przeciwstawnej jej postawie skromności, której charakterystyka $\mathrm{w}$ wielu punktach jest zbieżna $\mathrm{z}$ cnotą pokory:

„demon [próżnej chwały] [...] ma twarz powabną. [...] Z zewnętrznego wyglądu jest piękna i czarująca, spróbujmy ją jednak zatrzymać, a zaraz ściągnie naszą duszę do pyłu. [...] Cieszymy się pochwałami za rzeczy, w których nie mamy najmniejszej zasługi. Nawet ubogi chce pokazać się w pięknych szatach, aby tylko znaleźć u drugich uznanie. [...] Gdyby srebrne naczynia były konieczne do życia, większa część ludzkości już by nie żyła, bo większość nie ma srebra. Gdy więc postawimy właścicielowi srebra pytanie: «Po co masz tę rzecz? Wskaż mi jej cel, czemu ona służy?» - nie poda innego powodu, jak tylko chwałę u ludzi. «Mam to - powie - by mnie ludzie podziwiali, a nie lekceważyli. Schowam je też, by mi nie zazdroszczono i nie skradziono». Czyż może być większa głupota? Jeśli masz srebro dla chwały u ludzi, wystaw je na oczy wszystkich, jeśli boisz się zazdrości, zrobisz lepiej, gdy go nie będziesz posiadał. [...] Mówię zatem: Źródłem uznania nie jest dom wspaniały, nie ozdobne łóżko, nie chmara służby. Wszystko to leży poza nami i nie daje nam wcale wartości. Jeśli co stanowi prawdziwą wartość, to skromność

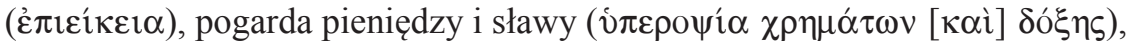
małe cienie pochwał ze strony tłumu, zamiłowanie w ubóstwie, wyniesienie naszej ludzkiej natury przez cnotliwe życie - to daje uznanie, to przynosi

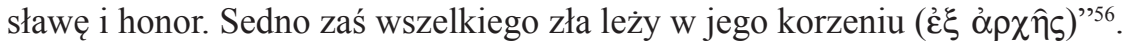

Chociaż w powyższym tekście nie padają terminy „pycha” ani „pokora”, całe pouczenie Jana Chryzostoma obraca się wokół tych postaw. Próżna chwała, przejawiająca się w zdobywaniu dóbr tego świata w nadziei, że będzie można zyskać na znaczeniu i zająć wyższe miejsce społeczne, to wyraźny przejaw pychy, która szuka chwały w sobie i rzeczach ziemskich, zamiast w Bogu i sprawach nieprzemijających, a przy okazji gardzi innymi ludźmi. Charakte-

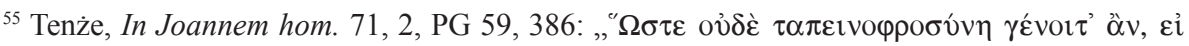

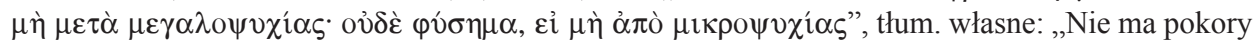
bez wielkoduszności, a pycha ma za jedyną przyczynę małoduszność”; tenże, In Epistulam I ad Corinthios hom. 1, 2-3, PG 61, 15.

${ }^{56}$ Tenże, De inani gloria et de educandis liberis 2. 3. 13. 15, ed. A.-M. Malingrey, SCh 188, Paris 1972, 68-74. 90-96, tłum. W. Kania: Św. Jan Chryzostom, O wychowaniu dzieci, w: Św. Jan Chryzostom, O matżeństwie, wychowaniu dzieci i ascezie, BOK 19, Kraków 2002, 74-79. 
rystyka przeciwstawiającej się jej skromności, w której przewija się małość i ubóstwo, wyraźnie nawiązuje do postawy pokory zadowalającej się tym, co małe, i szukającej chwały u Boga, a nie w sobie. Kończące wywód Jana Chryzostoma stwierdzenie o „korzeniu wszelkiego zła” jednoznacznie wskazuje na pychę, ponieważ tym określeniem nazywał ją w innych swoich dziełach.

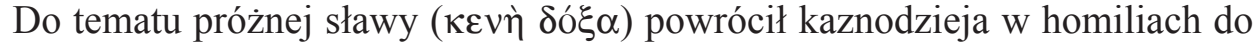
Ewangelii św. Mateusza, określając ją ponownie jako najgwałtowniejszą ze

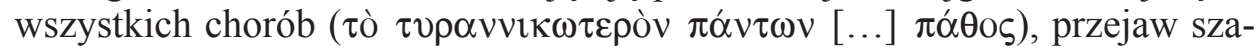

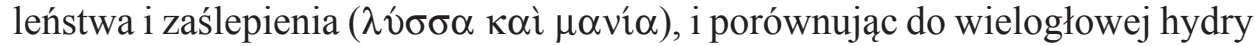

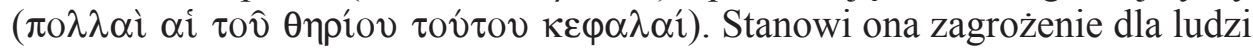

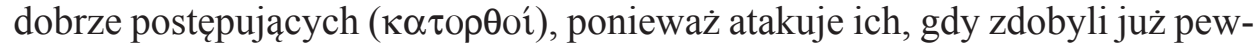
ne cnoty ${ }^{57}$.

Pychę łączył Jan Chryzostom z zarozumiałością oraz bezwstydną i trudną do powstrzymania chełpliwością ( $\mu \varepsilon \gamma \alpha \lambda \eta \gamma$ ○í $\alpha$ ) i brakiem powściągliwości

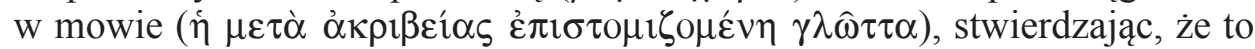
najbardziej zgubne grzechy, tłumione jako największe niebezpieczeństwo moralne już w Starym Testamencie przez Prawo i Proroków ${ }^{58}$. Złotousty kaznodzieja podkreślał, że pycha nie tylko niszczy relacje osobiste, ale ma także negatywny wydźwięk ogólnospołeczny i antywspólnotowy: ,nic tak nie rozrywa

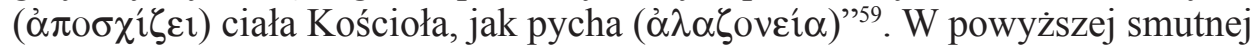
konstatacji można wyczuć kontekst antyheretycki, wszak główną przyczyną odejścia od ortodoksji był, zdaniem jednego z Kapadocczyków - Grzegorza z Nazjanzu, brak umiarkowanego, pokornego myślenia o Bogu. Z pewnością na powyższą ocenę nie pozostała bez wpływu także sytuacja rywalizacji między stolicami biskupimi i własne doświadczenia Jana Chryzostoma związane z decyzjami władzy cesarskiej wobec jego osoby.

Spory z heretykami, dotyczące trudnych i owianych tajemnicą kwestii trynitarnych sprawiły, że Jan, podobnie jak Grzegorz z Nazjanzu, również poruszał problem przesadnej, inspirowanej pychą ciekawości prowadzącej do wnikania w naturę Boga i zniekształcania nauki apostolskiej ${ }^{60}$. Anomejczykom zarzucał chęć takiego poznania Boga, jakie może mieć tylko On sam o sobie, podczas gdy w tych sprawach należy zachować skromność i umiarkowanie. Złotousty zwraca uwagę, że nawet aniołowie nie są w stanie pojąć w pełni Boga, człowiek z kolei nie może przeniknąć swoim umysłem substancji aniołów ani nawet poznać swojej własnej duszy ${ }^{61}$. Swoistym ,produktem” braku pokory w Kościele są nie tylko heretycy głoszący nieortodoksyjne poglądy,

${ }^{57}$ Por. tenże, In Matthaeum hom. 19, 1, PG 57, 273, ŹMT 18, 239; 71, 2, PG 58, 664, ŹMT 23, 347-348.

${ }^{58}$ Por. tenże, In Epistulam ad Romanos hom. 7, 1, PG 60, 442, tłum. Sinko, I/1, 105.

${ }^{59}$ Tamże 22, 2, PG 60, 610, thum. Sinko, I/2, 352.

${ }^{60}$ Por. tenże, In Epistulam II ad Corinthios hom. 23, 2, PG 61, 555-556.

${ }^{61}$ Por. tenże, De incomprehensibili Dei natura (Contra Anomoeos hom.) II 149-312, SCh 28bis, 154-166; tamże III 60-352, SCh 28bis, 190-216. 
ale także bliscy im lub nieraz z nimi się utożsamiający schizmatycy rozbijają-

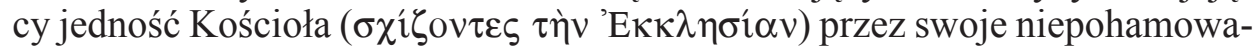
ne zamiłowanie do rządzenia i dominacji ( $\varphi \imath \lambda \alpha \rho \chi i \alpha \varsigma$ vó $\sigma o \varsigma)^{62}$.

Ostrzegając ludzi dążących do doskonałości przed zagrożeniem ze strony pychy Jan Chryzostom zwrócił uwagę na pewną charakterystyczną prawidłowość. Prawdziwa pokora jest przeciwieństwem pychy ${ }^{63}$. Między wadą a zniekształconą postacią przeciwstawnej jej cnoty może jednak istnieć bardzo płynna granica. Można bowiem pysznić się własną pokorą i czerpać z tego przyjemność. Wtedy pokora, nawet prawdziwa, może niepostrzeżenie przeradzać się w pychę i stawać się poniekąd jej źródłem. Dlatego w podkreślaniu konieczności nabywania cnoty pokory Jan Chryzostom szedł jeszcze dalej niż Bazyli, uważając, że sprawiedliwi powinni strzec się pychy i zabiegać o pokorę z większą troską niż grzesznicy. Jego zdaniem ,sumienie grzesznika w sposób oczywisty zobowiązuje go do pokory, podczas gdy sprawiedliwy wynosi się w poczuciu swoich dobrych czynów" ${ }^{\prime 2}$. Jest więc bardziej zagrożony pychą i utratą pokory, gdyż - jak mówi Złotousty: „,nic nie rodzi pychy łatwiej niż dobre sumienie, jeżeli nie stoi się na jego straży"65.

\section{HUMILITY IN THE FIGHT AGAINST A PRIDE - \\ FUNDAMENTAL SPIRITUAL AND MORAL CONTROVERSY ACCORDING TO CAPPADOCIAN FATHERS AND JOHN CHRYSOSTOM}

\section{(Summary)}

The aim of the article is to show the specificity of the fundamental fight in the soul and in the life of man between pride ( $v \pi \varepsilon \rho \eta \varphi \alpha v i \alpha)$ and humility ( $\tau \alpha-$

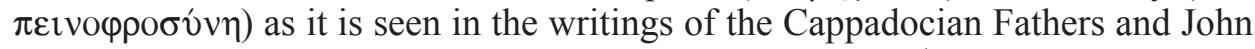
Chrysostom. In the opinion of the Greek Fathers of the $4^{\text {th }}$ century pride is the root of all sin. It destroys all good fruits in the Christian spiritual development, whereas humility enables and protects spiritual growth. Arguing against the heretics of their time, mainly against the Arians, the Cappadocian Fathers (especially Gregory of Nazianzus) made particular attention to the theologians' pride, characterized by the lack of respect for the mysteries of God and being proud that is

${ }^{62}$ Por. tenże, In Epistulam ad Ephesios hom. 11, 4-5, PG 62, 86.

${ }^{63}$ Por. tenże, In Epistulam ad Phillippenses hom. 5, 3, PG 62, 216-218.

${ }^{64}$ Tenże, Homiliae in illud: Vidi Dominum (In Osiam hom.) 4, 4, SCh 277, 158-162: „ó ó $\mu \alpha \rho \tau \omega \lambda$ òs

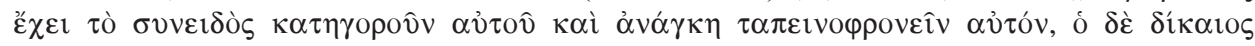
$\dot{\varepsilon} \pi \alpha i ́ p \varepsilon \tau \alpha \imath \kappa \alpha \tau o \rho \theta \omega ́ \mu \alpha \sigma \imath v "$. Chryzostom podaje przykład króla Ozjasza, który będąc człowiekiem sprawiedliwym, ostatecznie popadł w pychę i uzurpował sobie prawo do składania ofiar w świątyni jako kapłan (por. Iz 6).

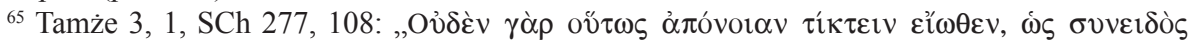

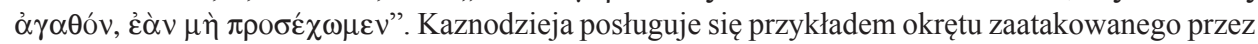
piratów, którzy szukają przede wszystkim miejsca przechowywania drogocennych towarów. Podobnie zachowuje się szatan wbijając w pychę człowieka cnotliwego. Por. tamże 4, 4, SCh 277 , 158-162. 
without moderation ( $\mu \varepsilon \sigma o ́ \tau \eta \varsigma)$ in talking about God. Gregory of Nyssa pointed out the perversity of the vice of pride: the arbitrary exaltation leads finally to the great unwanted humiliation and even to fall into the sin. John Chrysostom emphasized the paradoxical risk characteristic of the process of spiritual fight: one can brag because of owned humility and enjoy it. Then even true humility can imperceptibly transform into pride and become its source. Therefore the righteous people should avoid the pride and seek humility with more care than sinners.

Słowa kluczowe: pokora, pycha, walka duchowa, Ojcowie Kapadoccy, Jan Chryzostom.

Key words: humility, pride, spiritual fight, Cappadocian Fathers, John Chrysostom. 
